Jurnal SPORTIF: Jurnal Penelitian Pembelajaran

Vol. 6 No. 2, Agustus 2020, pp. 272-287

do) https://doi.org/10.29407/js_unpgri.vi.14101

\title{
Pengaruh kelelahan terhadap perubahan kinematika gerak pada saat overhead jumping smash dalam permainan bulutangkis
}

\section{Fatigue effect on movement kinematic changes of overhead jumping smash in badminton}

\section{Agus Rusdiana}

\begin{abstract}
Program Studi Ilmu Keolahragaan, Fakultas Pendidikan Olahraga dan Kesehatan, Universitas Pendidikan Indonesia. Jalan Dr. Setiabudi No.229 Bandung, West Java, 40154, Indonesia
\end{abstract}

Received: 14 January 2020; Revised: - ; Accepted: 11 April 2020

\begin{abstract}
Abstrak
Tujuan penelitian ini adalah untuk mengetahui pengaruh kelelahan kardiovaskular terhadap perubahan kinematika gerak pada tubuh bagian atas saat pukulan overhead jumping smash dalam permainan bulutangkis. Metode yang digunakan adalah deskriptif kuantitatif dengan pendekatan pre test and post test design. Sampel yang digunakan adalah pemain bulutangkis putra yang mempunyai keterampilan teknik overhead jumping smash dengan rata-rata usianya $19.4 \pm 1.6$ tahun, tinggi badan $1.73 \pm 0.12 \mathrm{~m}$ dan berat badan $60.8 \pm$ $3.7 \mathrm{~kg}$ dengan jumlah keseluruhan 12 orang. Penelitian ini menggunakan satu buah 3D force platform device, 3 buah Panasonic handycam, Frame DIAZ IV 3D motion software analysis, cosmed direct gas analyzer dan radar speed gun. Hasilnya menunjukkan bahwa pada fase maximum angular velocity terdapat perbedaan signifikan pada empat variabel saat kondisi fatigue dan non fatigue antara lain shoulder internal rotation $(P=0.042)$, elbow extension $(P=0.035)$, forearm supination $(P=0.024)$ dan wrist dorsi flexion $(P=0.040)$. Selanjutnya pada fase instant of maximal shoulder external rotation terdapat tiga variabel perbedaan yang signifikan antara lain shuttlecock velocity $(P=0.035)$, shoulder external rotation $(P=0.048)$, dan wrist palmar flexion $(P=0.037)$. Kesimpulan bahwa internal shoulder rotation, wrist palmar flexion dan forearm supination memberikan kontribusi yang sangat signfikan terhadap kecepatan shuttlecock pada saat melakukan overhead jumping smash dalam permainan bulutangkis.
\end{abstract}

Kata kunci: biomekanika, jumping smash, kecepatan shuttlecock, bulutangkis.

\begin{abstract}
The purpose of this study is to determine fatigue effect on the changes of Movement parameter kinematic in the upper body during overhead jumping smash in badminton. The method used in this study is quantitative descriptive with pre-test and post-test design approach. The sample is 12 male badminton university players who have overhead jumping smash technical with an average age of $19.4 \pm 1.6$ years, height $1.73 \pm 0.12 \mathrm{~m}$ and weight of $60.8 \pm 3.7 \mathrm{~kg}$. This study employs a 3D force platform device, 3 Panasonic camera, motion analysis software Frame DIAZ IV, cosmed direct gas analyzer and radar speed gun. The results show that in the maximum angular velocity phase, there are significant differences in the four variables during fatigue and non-fatigue conditions including shoulder internal rotation $(P=0.042)$, elbow extension $(P=0.035)$, forearm supination $(P=0.024)$ and wrist dorsi flexion $(P=0.040)$. Furthermore, in
\end{abstract}

Correspondence author: Agus Rusdiana, Universitas Pendidikan Indonesia, Indonesia.

Email: agus.rusdiana@upi.edu 
the instant of maximal external shoulder rotation phase, there are three significant differences including shuttlecock velocity $(P=0.035)$, shoulder external rotation $(P=0.048)$ and wrist palmar flexion $(P=0.037)$. The conclusion is the internal shoulder rotation, wrist palmar flexion and forearm supination contribute significantly to shuttlecock velocity during overhead jumping smash in badminton.

Keywords: biomechanics, jumping smash, shuttlecock velocity, badminton.

\section{PENDAHULUAN}

Penelitian tentang biomekanika yang terkait dengan overhead smash dalam permainan bulutangkis sangat minim dilakukan, akan tetapi kajian pembahasan dari cabang olahraga lain yang sangat mirip dengan mekanisme rangkaian gerak overhead smash sudah banyak di publikasikan seperti pada gerak servis dan smash olahraga tenis, lemparan bola tangan, lemparan bola cricket dan lemparan pitcher baseball yang dapat membantu memberikan kajian wawasan luas tentang kinematika gerak overhead smash dalam permainan bulutangkis (Mei, Gu, Fu, \& Fernandez, 2016). Pukulan overhead smash dapat dikatagorikan ke dalam dua kelompok yaitu yang dilakukan dalam sikap berdiri (standing smash) dan sambil meloncat (jumping smash) (Phomsoupha \& Laffaye, 2014).

Pukulan jumping smash dapat menghasilkan kecepatan shuttlecock maksimal dalam upaya mematikan pergerakan lawan serta meraih angka sebanyak mungkin dengan kontribusi mencapai 39.8\% (Sakurai \& Ohtsuki, 2010). Selain itu, laju shuttlecock yang dihasilkan dari pukulan tersebut melebihi kecepatan bola pada olahraga raket lainnya dengan mencapai 493 km/jam yang lakukan pemain China Tan Boon Heong pada saat melakukan uji coba sebuah produk raket baru (Yonex ArcSaber Z-Slash) pada tahun 2013 (Reid, Giblin, \& Whiteside, 2015). Kemudian pemain ganda putra China Fu Haifeng yang menghasilkan kecepatan shuttlecock sekitar 332 km/jam pada kejuaran Sudirman Cup tahun 2005 (Lam, Ding, \& Qu, 2016). Selain itu, pada nomor tunggal putra pemain Indonesia Taufik Hidayat mencapai kecepatan shuttlecock $305 \mathrm{~km} / \mathrm{jam}$ pada kejuaraan dunia tahun 2006 (Rusdiana, 2016). 
Beberapa hasil penelitian yang sudah dilakukan di tennis serve dan overarm throw baseball menunjukkan bahwa perluasan ruang gerak pada persendian dapat memberikan kontribusi lebih besar terhadap kecepatan dan akselerasi gerakan segmen tubuh (Alcock \& Cable, 2009). Kemudian, faktor yang mempengaruhi kecepatan shuttlecock adalah pergerakan sendi tangan (palmar flexion at wrist joint) atau disebut juga "wrist snap" yang memberikan kontribusi sekitar 20\% (Gawin, Beyer, \& Seidler, 2017). Selain itu, gerak pada sendi lengan forearm pronation supination memberikan pengaruh signifikan pada kecepatan shuttlecock sekitar $10 \%$ (Gawin et al., 2017). Peran dominan gerak sendi bahu pada ayunan rotasi maksimal ke belakang yang dilanjutkan gerakan rotasi ke depan (external internal shoulder rotation) sampai pada gerak lanjutan (follow through) merupakan faktor utama dalam menghasilkan kecepatan bola dengan berkontribusi lebih dari 40\% pada gerak smash tennis (Gordon, 2006).

Pukulan jumping smash merupakan rangkaian koordinasi gerak bagian tubuh secara keseluruhan yang berkesinambungan. Sedangkan koordinasi gerak dipengaruhi oleh otot rangka yang fungsinya disebabkan oleh rangsangan yang dilakukan oleh saraf motorik somatik dalam usaha menggerakkan anggota tubuh (Abián et al., 2017). Fungsi utama otot rangka adalah kontraksi yang akan mengakibatkan terjadi perubahan posisi yang disebut dengan "motor segment movement" (Wagner, Pfusterschmied, Duvillard, Müller, \& Mu, 2011). Pemain melakukan pukulan jumping smash membutuhkan tenaga yang maksimal dan gerakan yang komplek dengan dukungan komponen fisik diantaranya power otot tungkai, kekuatan otot lengan, kekuatan otot perut, kekuatan otot lengan, dan tangan (Hirashima, Kadota, Sakurai, \& Kudo, 2010).

Kontraksi otot yang kuat dan lama saat memukul terus menerus selama latihan atau bertanding akan berdampak kepada sumber energi dalam tubuh terus berkurang yang menyebabkan terjadinya kelelahan (Ooi, Tan, Ahmad, Kwong, \& Sompong, 2009). Selain itu, berkurangnya energi menjadi penyebab menurunnya kekuatan dan kecepatan kontraksi otot yang berdampak terhadap rangsangan perintah menjadi lebih lambat 
(Mansec, Pageaux, Nordez, \& Dorel, 2017). Dengan demikian semakin lambat dan tidak terkontrol gerakan akan menunjukkan semakin lelah kondisi otot seseorang (Aragonés et al., 2017).

Dari penjelasan uraian latar belakang diatas, tujuan penelitian ini adalah untuk mengetahui pengaruh kelelahan kardiovaskular terhadap perubahan indikator parameter kinematika khususnya gerak pada tubuh bagian atas saat pukulan overhead jumping smash dalam permainan olaharaga bulutangkis.

\section{METODE \\ Partisipan}

Partisipan dalam penelitian ini adalah pemain yang bergabung dalam unit kegiatan mahasiswa bulutangkis Universitas Pendidikan Indonesia yang berjumlah 56 orang. Sedangkan sampel yang digunakan adalah pemain bulutangkis putra yang mempunyai keterampilan teknik overhead jumping smash dengan rata-rata usianya $19.4 \pm 1.6$ tahun, tinggi badan $1.73 \pm 0.12 \mathrm{~m}$ dan berat badan $60.8 \pm 3.7 \mathrm{~kg}$ dengan jumlah keseluruhan 12 orang.

\section{Metode}

Metode yang digunakan dalam penelitian ini adalah deskriptif kuantitatif dengan pendekatan pre test and post test design.

\section{Instrumen}

Penelitian ini adalah menggunakan satu buah 3D Force Platform Device (AMTI OR6), 3 buah Panasonic Handycam HC-V100 Full HD, satu unit high speed camera (Phantom USA), satu set kalibrasi 3 dimensi, Frame DIAZ IV 3D motion software analysis, Cosmed direct gas analyzer dan radar speed gun. Sedangkan tempat pengambilan data dilakukan di sport hall dan sport science laboratory FPOK UPI. Adapun peralatan yang digunakan untuk mengukur indikator kelelahan adalah seperangkat alat pengukur fisiologi Fitmate MED (COSMED srl-Italy) terdiri dari heart rate transmitter, heart rate receiver, $V$ mask (Hans Rudolph Inc), dan treadmill SportArt@60. Protokol treadmill yang dilakukan adalah menggunakan protokol maximal test. 


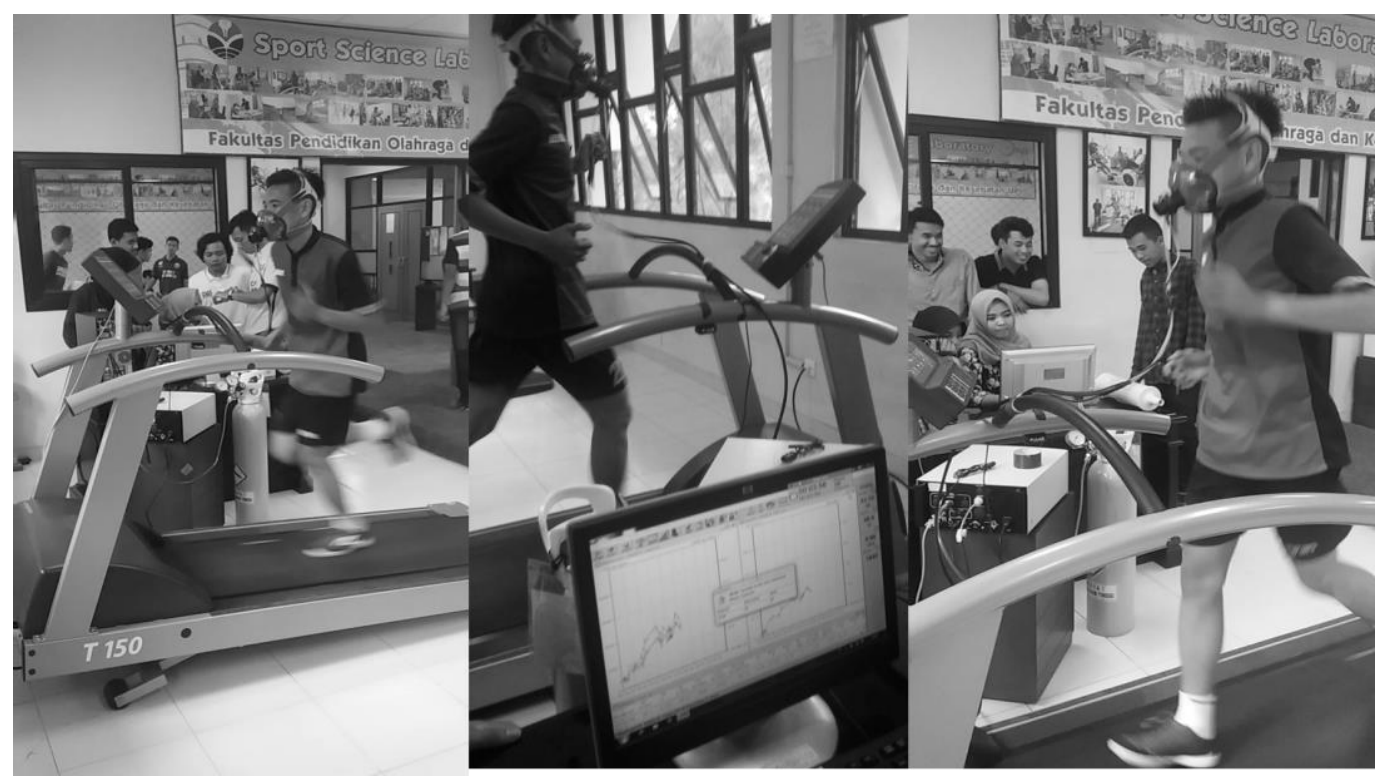

Gambar 1. Pengukuran kelelahan di sport science laboratory FPOK UPI

\section{Parameter Kinematika Gerak}

Untuk mengetahui karakteristik mekanika pukulan jumping smash maka dilakukan pembuatan model sesuai dengan prinsip anatomi gerak yaitu pada sendi bahu yang terdiri dari tiga karakteristik gerakan antara lain internal external shoulder rotation (A), shoulder abduction-adduction (B) dan shoulder horizontal abduction-adduction (C).
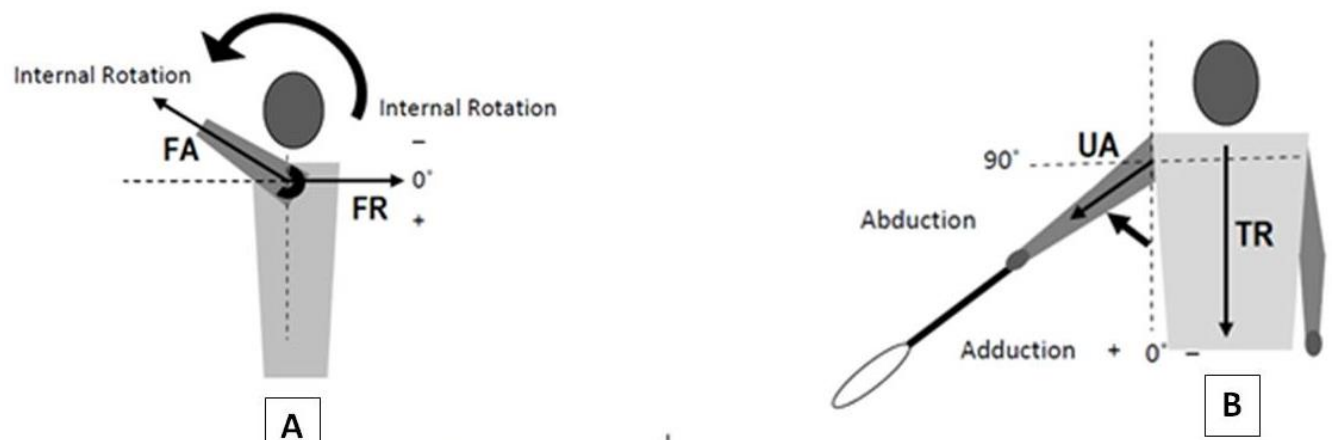

A

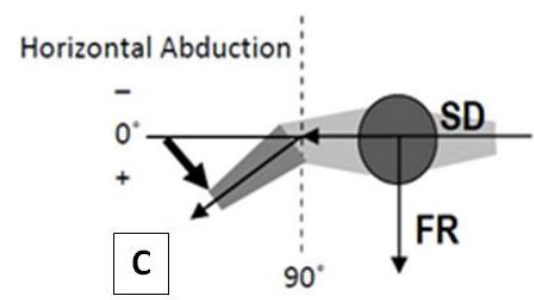

Horizontal Adduction 
Pada sendi sikut yang terdiri dari dua karakteristik gerakan yaitu elbow flexion-extension (D) dan forearm pronation-supination (E).
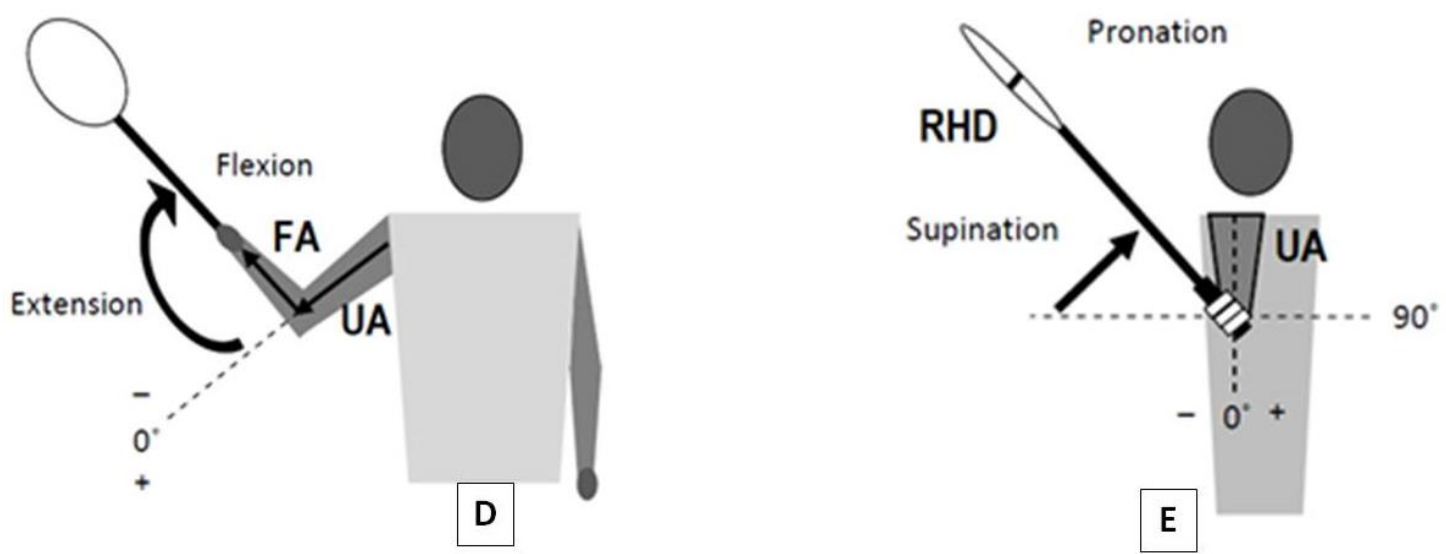

Pada sendi pergelangan tangan yang terdiri dari dua karakteristik gerakan yaitu palmar-dorsi flexion $(\mathrm{F})$ dan radial-ulnar flexion $(\mathrm{G})$.

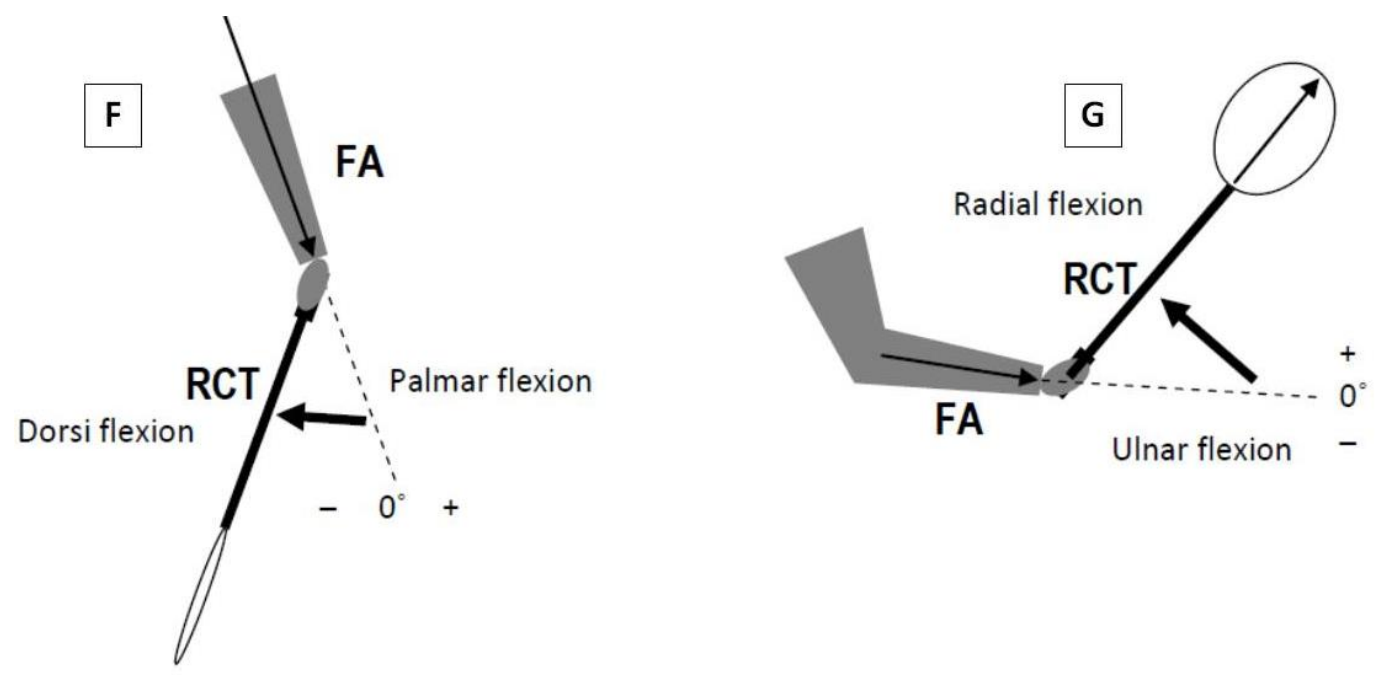

Berikutnya adalah gerakan upper torso rotation dan pelvis rotation $(\mathrm{H})$, trunk tilt forward dan trunk tilt backward (I) serta trunk tilt left and right sideways (J). 

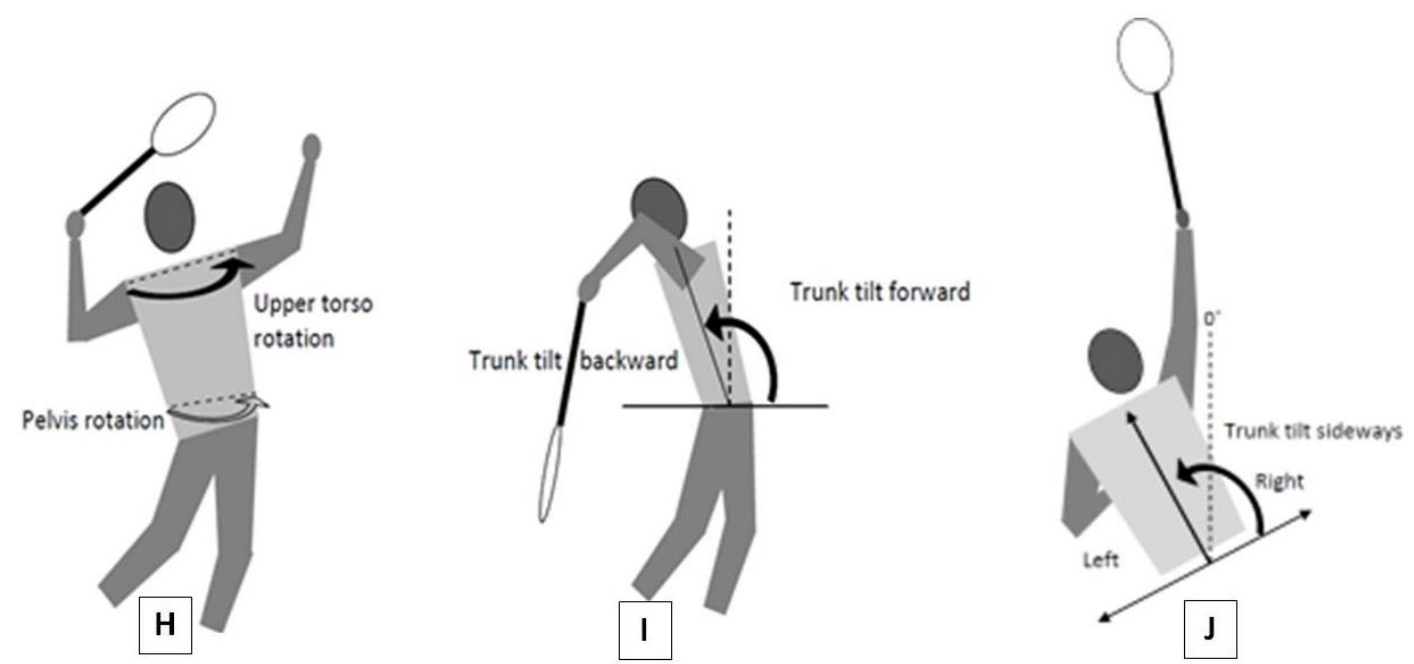

Gambar 2. Parameter kinematika gerak pada sendi tubuh bagian atas (Sumber: Rusdiana, 2016)

\section{Prosedur Pengambila Data}

Untuk mengukur kecepatan shuttlecock menggunakan satu buah speed radar gun yang di pasang di samping lapangan. Kamera 1 ditempatkan diatas tegak lurus pada subject area dengan jarak 5m, tujuannya adalah mendapatkan rekaman gerakan sendi bahu dan panggul pada saat melakukan jumping smash. Sedangkan kamera 2 diposisikan di samping kanan subject area, kamera 3 ditempatkan tegak lurus dibelakang subject area dengan tujuan mendapatkan gambaran komprehensif gerakan seluruh persendian pada tubuh bagian atas serta hasil loncatan dari jumping smash. Satu buah pelontar shuttlecock machine di letakkan tegak lurus di area lapangan yang berlawanan dengan subject area dengan tujuan agar akurasi dan kecepatan shuttlecock lebih stabil. 


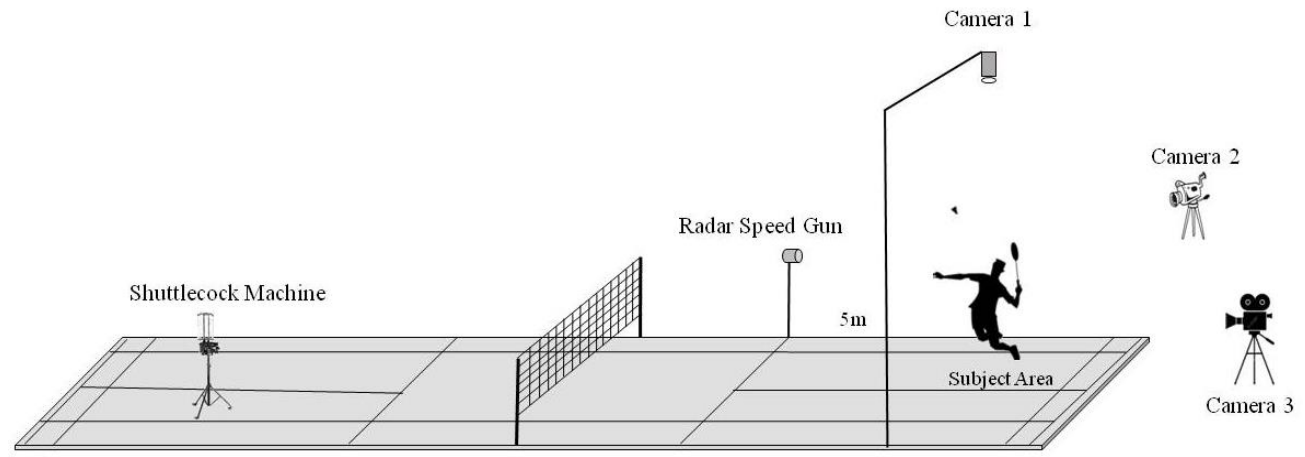

Gambar 3. Skema pengambilan data lapangan

Pemain diberikan kesempatan melakukan jumping smash sebanyak 10 kali secara bergantian dengan tujuan untuk menghindari kelelahan setelah melakukan pemanasan sekitar 10 menit pada pengambilan data tahap pertama. Pada tahap kedua pemain terlebih dahulu diberikan tes kelelahan dengan menggunakan heart rate monitor yang diintegrasikan dengan treadmill ergometer. Setelah itu, pemain melakukan pukulan jumping smash sebanyak 10 kali secara terus menerus.

\section{HASIL}

Berikut ini penjelasan analisis data terkait perbedaan kecepatan shuttlecock dan perubahan kinematika gerak pada saat fatigue dan non fatigue pada saat melakukan overhead jumping smash dalam permainan bulutangkis.

Tabel 1. Parameter kinematic pada fase instant of maximal shoulder external rotation

\begin{tabular}{lcc}
\hline \multirow{2}{*}{ Kinematic Parameter Analysis } & Means & \pm SD \\
\cline { 2 - 3 } & Fatigue & Non Fatigue \\
\hline Shuttlecock velocity (km/h)* & $145 \pm 5.7$ & $188 \pm 3.5$ \\
Jump height (cm) & $43 \pm 6.8$ & $46 \pm 5.1$ \\
Shoulder external rotation (deg) & $-162 \pm 3.5$ & $-134 \pm 4.2$ \\
Shoulder abduction (deg) & $101 \pm 1.2$ & $106 \pm 1.4$ \\
Shoulder horizontal adduction (deg) & $7 \pm 0.83$ & $9 \pm 0.96$ \\
Elbow flexion (deg) & $94 \pm 1.1$ & $102 \pm 1.3$ \\
Forearm pronation (deg) & $14 \pm 1.1$ & $1 \pm 1.3$ \\
Wrist palmar flexion (deg) & $-21 \pm 2.1$ & $-47 \pm 2.4$ \\
Trunk tilt backward (deg) & $21 \pm 3.5$ & $24 \pm 3.1$ \\
Trunk tilt sideways left (deg) & $19 \pm 1.4$ & $21 \pm 1.6$ \\
\hline
\end{tabular}

${ }^{*}$ Perbedaan signifikansi pada taraf 0.05 
Pada tabel 1 menunjukkan bahwa dari sepuluh kinematic parameter pada fase instant of maximal shoulder external rotation terdapat perbedaan signifikan pada tiga variabel pada kondisi fatigue dan non fatigue antara lain shuttlecock velocity $(P=0.035)$, shoulder external rotation $(P=0.048)$ dan wrist palmar flexion $(P=0.037)$.

Tabel 2. Parameter kinematic pada fase maximum angular velocity

\begin{tabular}{|c|c|c|}
\hline \multirow{2}{*}{ Kinematic Parameter Analysis } & \multicolumn{2}{|c|}{ Means \pm SD } \\
\hline & Fatigue & Non Fatigue \\
\hline Shoulder internal rotation (deg/s)* & $1623 \pm 3.5$ & $2111 \pm 4.2$ \\
\hline Upper torso rotation (deg/s) & $761 \pm 1.2$ & $782 \pm 1.4$ \\
\hline Pelvis rotation (deg/s) & $421 \pm 0.83$ & $429 \pm 0.96$ \\
\hline Elbow extension $(\mathrm{deg} / \mathrm{s})^{*}$ & $776 \pm 1.1$ & $985 \pm 1.3$ \\
\hline Forearm supination (deg/s)* & $442 \pm 1.1$ & $694 \pm 1.3$ \\
\hline Wrist dorsi flexion (deg/s) ${ }^{*}$ & $413 \pm 2.1$ & $855 \pm 2.4$ \\
\hline Trunk tilt forward (deg/s) & $185 \pm 3.5$ & $199 \pm 3.1$ \\
\hline
\end{tabular}

* Perbedaan signifikansi pada taraf 0.05

Pada tabel 2 menunjukkan bahwa dari tujuh kinematic parameter pada fase maximum angular velocity terdapat perbedaan signifikan pada empat variabel pada saat kondisi fatigue dan non fatigue antara lain shoulder internal rotation $(P=0.042)$, elbow extension $(P=0.035)$, forearm supination $(P=0.024)$ dan wrist dorsi flexion $(P=0.040)$.

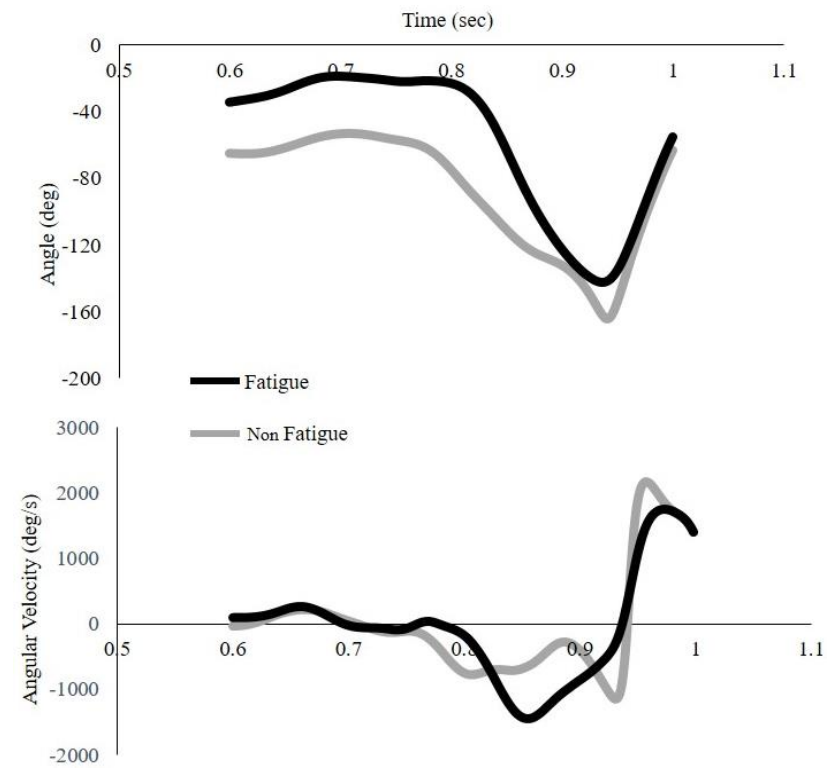

Gambar 4. Perubahan maksimal sudut dan kecepatan rotasi pada sendi bahu (shoulder internal rotation) 
Gambar 4 menunjukkan perbedaan yang signifikan pada perubahan sudut gerakan shoulder external rotation $\left(-162^{\circ}\right.$ vs $\left.-134^{\circ}\right)$ dan kecepatan internal shoulder angular velocity $\left(1623^{\circ} / \mathrm{s}\right.$ vs $\left.2111^{\circ} / \mathrm{s}\right)$ pada saat kondisi fatigue dan non fatigue.

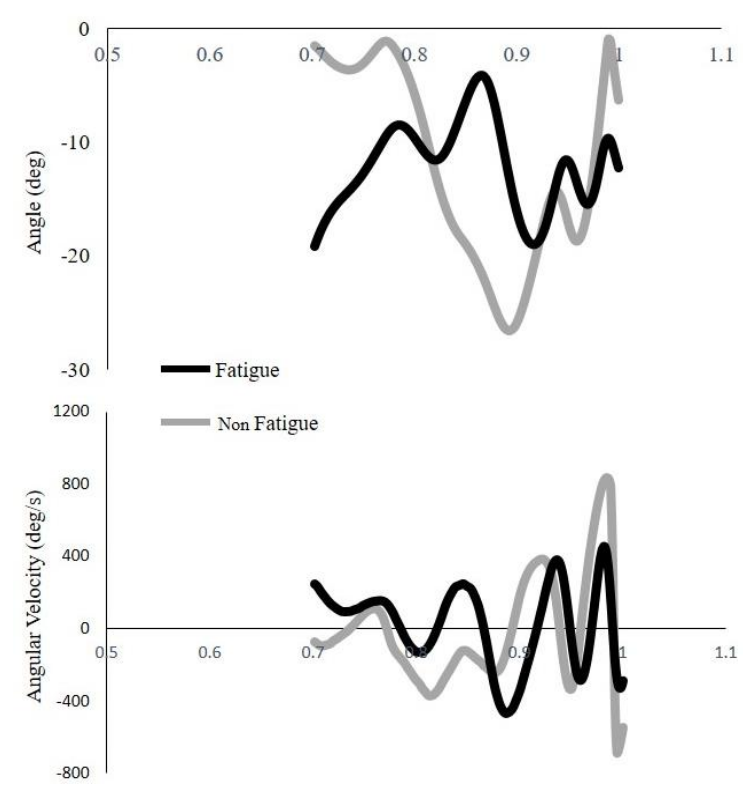

Gambar 5. Perubahan sudut dan kecepatan rotasi pada sendi tangan (wrist fexion extension angular velocity)

Gambar 5 menunjukkan perbedaan yang signifikan pada perubahan gerak sudut maksimal wrist palmar flexion $\left(-21^{\circ}\right.$ vs $\left.-47^{\circ}\right)$ dan kecepatan rotasi wrist dorsi flexion $\left(413 \%\right.$ s v $\left.855^{\circ} / \mathrm{s}\right)$ pada saat kondisi fatigue dan non fatigue. 


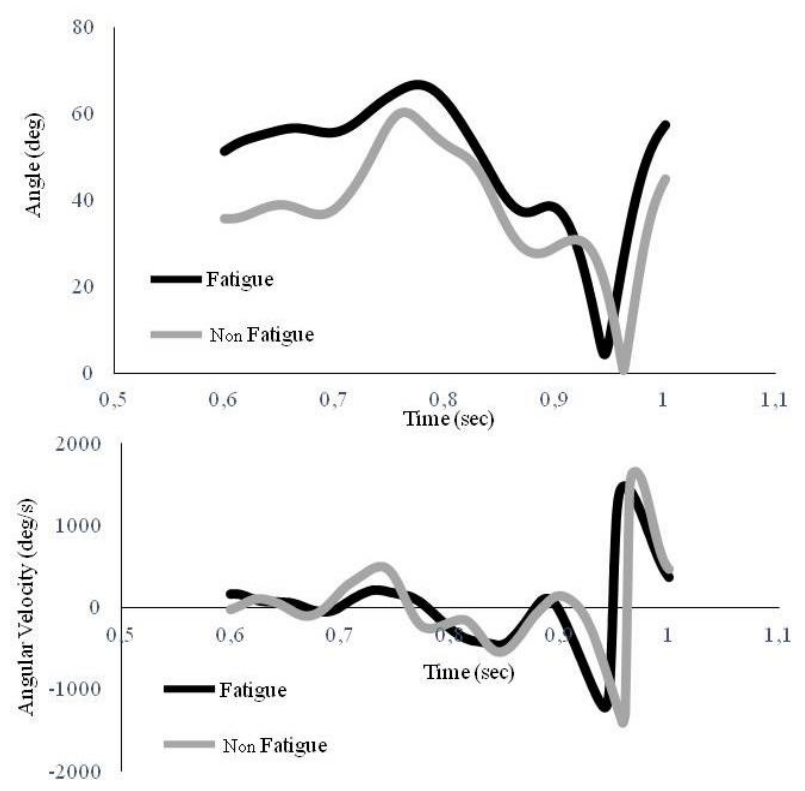

Gambar 6. Perubahan sudut dan kecepatan rotasi pada sendi lengan forearm pronation supination

Gambar 6 menunjukkan terdapat perbedaan yang signifikan pada perubahan sudut forearm pronation $\left(14^{\circ}\right.$ vs $1^{\circ}$ ) dan kecepatan putaran forearm supination (442\% vs $694 \%$ s) pada saat kondisi fatigue dan non fatigue.

Tabel 3. Parameter kinematic pada fase instant of shuttlecock release

\begin{tabular}{|c|c|c|}
\hline \multirow{2}{*}{ Kinematic Parameter Analysis } & \multicolumn{2}{|c|}{ Means \pm SD } \\
\hline & Fatigue & Non Fatigue \\
\hline Shoulder abduction (deg) & $23 \pm 3.5$ & $27 \pm 4.2$ \\
\hline Shoulder horizontal abduction (deg) & $14 \pm 1.2$ & $37 \pm 1.4$ \\
\hline Elbow extension (deg) & $78 \pm 1.1$ & $81 \pm 1.3$ \\
\hline Wrist palmar flexion (deg) & $5 \pm 1.1$ & $8 \pm 1.2$ \\
\hline Trunk tilt forward right (deg) & $17 \pm 3.5$ & $21 \pm 3.1$ \\
\hline
\end{tabular}

${ }^{*}$ Perbedaan signifikansi pada taraf 0.05

Pada tabel 3 menunjukkan hanya satu variabel perbedaan yang signifikan dari lima kinematic parameter pada fase instant of shuttlecock release pada saat kondisi fatigue dan non fatigue yaitu shoulder horizontal abduction. 


\section{PEMBAHASAN}

Rangkaian pola gerak dari pukulan overhead jumping smash membutuhkan kecepatan dan percepatan linier dan melingkar dari gerakan tubuh, shuttlecock dan ayunan raket. Sedikit sekali penelitian yang menjelaskan mekanisme gerak terkait teknik pukulan forehand overhead stroke terutama jumping smash. Tetapi, menurut Gordon (2006) dalam penelitiannya yang menganalisis tentang kontribusi kecepatan rotasi persendian tubuh bagian atas pada tennis serve menyatakan bahwa gerakan sendi bahu maksimal pada waktu raket mengayun ke belakang (shoulder external rotation) merupakan momentum awal untuk menghasilkan kecepatan rotasi bahu ke depan yang lebih cepat (shoulder internal rotation) sehingga mendapatkan kecepatan bola yang lebih besar (Gawin et al., 2017), seperti yang terlihat pada gambar 7.

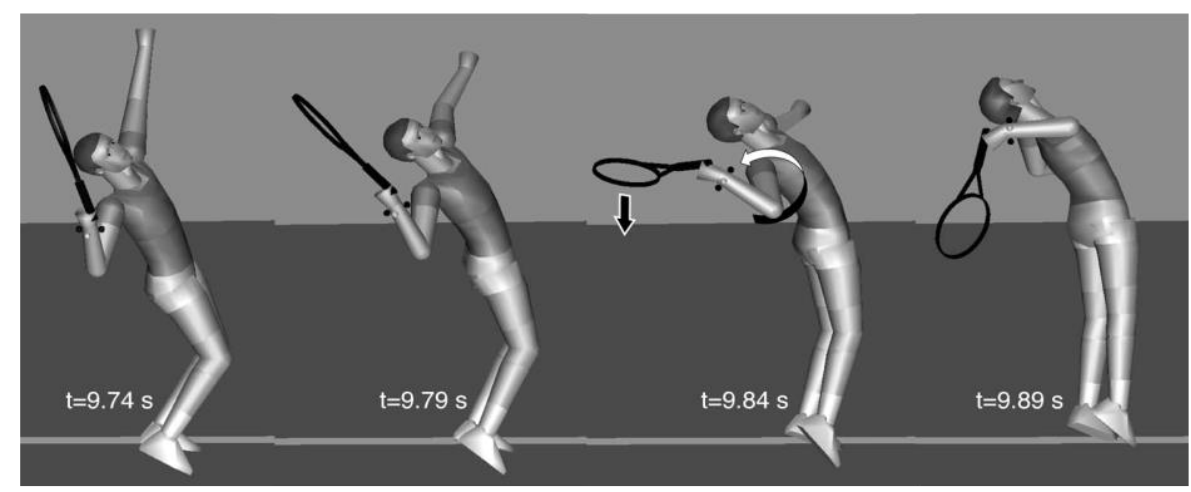

Gambar 7. Kontribusi shoulder external rotation pada waktu raket mengayun ke belakang. (Sumber: Gordon, 2006).

Hasil penelitian ini sejalan dengan temuan dari (Gordon, 2006) di tennis serve bahwa sendi sikut memberikan kontribusi terhadap kecepatan bola. Pada gerakan elbow extension semakin cepat berputar maka akan menghasilkan suatu dorongan yang kuat dari lengan bagian atas dan ayunan raket ke depan sebelum terjadi benturan dengan shuttlecock, seperti penjelasan gambar 8 dibawah ini. 


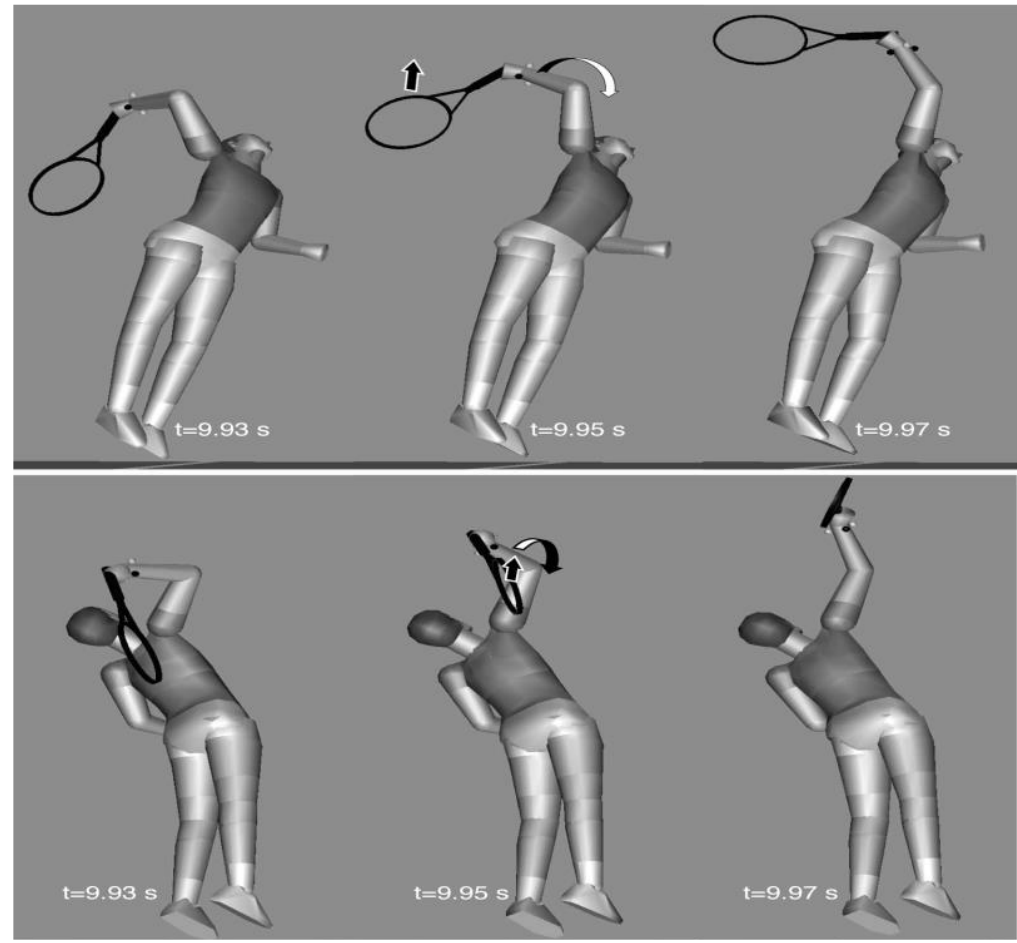

Gambar 8. Gerakan elbow flexion-extension (Sumber: Gordon, 2006).

Hasil daripada penelitian tersebut, menunjukkan bahwa gerakan fleksi dan ekstensi pada sendi sikut mencapai 30\% terhadap kecepatan ayunan raket. Kecepatan putaran dari sendi lainnya yang mempunyai peranan penting terhadap kecepatan ayunan raket adalah sendi sikut gerakan pronation-supination (Gordon, 2006). Gerakan sendi ini, terutama kecepatan putaran gerak supinasi dari lengan bagian bawah sesaat sebelum impact dengan shuttlecock memberikan dukungan yang besar terhadap kecepatan shuttlecock dan raket (Gawin et al., 2017).

Gerakan ini terlihat jelas apabila pemain yang mempunyai keterampilan teknik tinggi. Sedangkan untuk pemain pemula, biasanya gerakan tersebut hampir tidak terjadi. Maka tidak mengherankan pemain profesional menghasilkan kecepatan shuttlecock yang jauh lebih besar dibandingkan dengan pemain juniornya, seperti terlihat pada gambar 9 dibawah ini. 


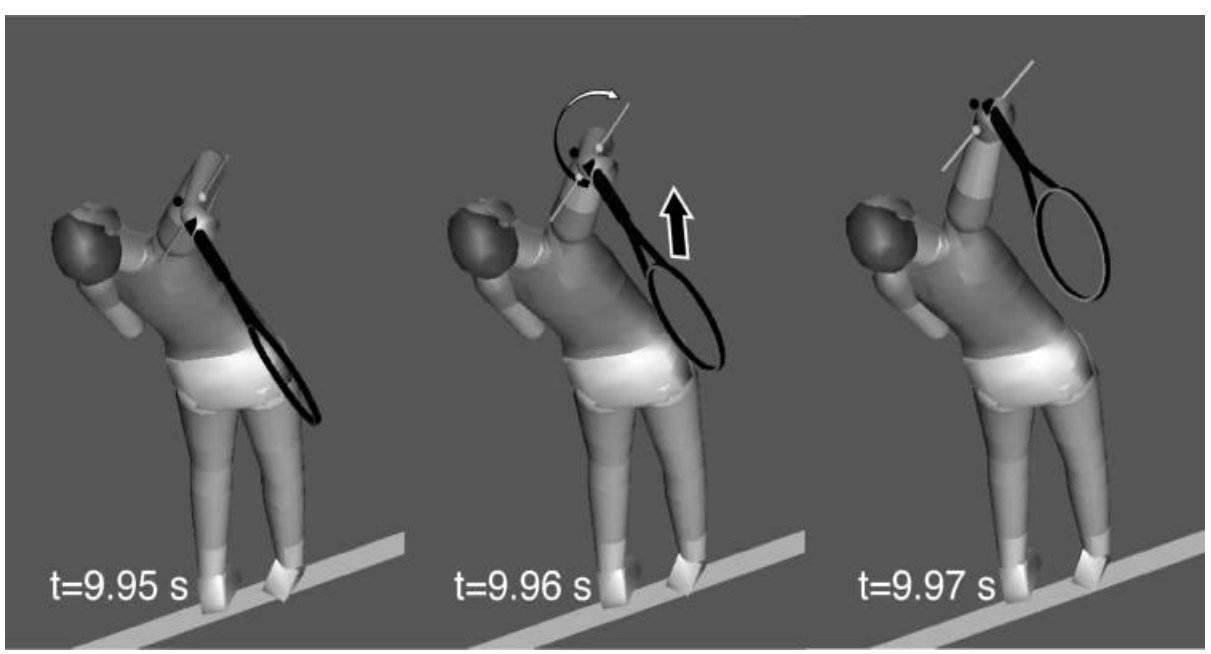

Gambar 9. Gerakan pronation-supination at radio ulnar joint sebelum terjadi impact (Sumber: Gordon, 2006).

\section{KESIMPULAN DAN SARAN}

\section{Kesimpulan}

Dari hasil dan pembahasan yang telah dijelaskan, menunjukkan suatu kesimpulan bahwa kecepatan shuttlecock pada saat melakukan pukulan jumping smash pada saat kondisi non faigue hasil lebih cepat dibandingkan pada saat fatigue. Hal ini disebabkan karena kelelahan otot yang terjadi setelah kontraksi otot yang kuat dan lama, di mana otot tidak mampu lagi berkontraksi dalam jangka waktu tertentu. Kelelahan otot menunjuk pada suatu proses yang mendekati definisi fisiologik yang sebenarnya yaitu berkurangnya respons terhadap stimulasi yang datang (Li, Zhang, Wan, Wilde, \& Shan, 2016). Ketika terjadi kelelahan maka pemain akan sulit mengatur dan mengontrol arah pergerakan laju shuttlecock. Kecepatan rotasi dari sendi bahu pada gerakan internal shoulder rotation, sendi lengan gerakan wrist palmar flexion serta sendi lengan bagian atas gerakan forearm supination memberikan kontribusi yang sangat signfikan terhadap kecepatan shuttlecock pada saat melakukan overhead jumping smash dalam permainan bulutangkis.

\section{Saran}

Setelah dilakukan analisa kajian secara komprehensif dari karakteristik teknik pukulan overhead jumping smash disarankan agar diberikan latihan beban khusus kepada pemain pada sendi bahu terutama 
gerakan shoulder internal external rotation, wrist flexion extension, elbow flexion extension dan forearm pronation-supination. Tujuan dari pemberian latihan beban secara khusus tersebut bertujuan untuk meningkatkan kekuatan dan power pada bahu, lengan, dan pergelangan tangan.

\section{REFERENSI}

Abián, P., Castanedo, A., Feng, X. Q., Sampedro, J., \& Abian-Vicen, J. (2014). Notational comparison of men's singles badminton matches between Olympic Games in Beijing and London. International Journal of Performance Analysis in Sport, 14(1), 42-53. https://doi.org/10.1080/24748668.2014.11868701

Alcock, A., \& Cable, N. T. (2009). A comparison of singles and doubles badminton: heart rate response, player profiles and game characteristics. International Journal of Performance Analysis in Sport, 9(2), 228-237. https://doi.org/10.1080/24748668.2009.11868479

Aragonés, D., Eekhoff, A., Horst, F., \& Schöllhorn, W. I. (2018). Fatiguerelated changes in technique emerge at different timescales during repetitive training. Journal of sports sciences, 36(11), 1296-1304. https://doi.org/10.1080/02640414.2017.1374758

Gawin, W., Beyer, C., \& Seidler, M. (2015). A competition analysis of the single and double disciplines in world-class badminton. International Journal of Performance Analysis in Sport, 15(3), 997-1006. https://doi.org/10.1080/24748668.2015.11868846

Gordon, B. J., \& Dapena, J. (2006). Contributions of joint rotations to racquet speed in the tennis serve. Journal of sports sciences, 24(1), 31-49. https://doi.org/10.1080/02640410400022045

Hirashima, M., Kadota, H., Sakurai, S., Kudo, K., \& Ohtsuki, T. (2002). Sequential muscle activity and its functional role in the upper extremity and trunk during overarm throwing. Journal of sports sciences, 20(4), 301-310. https://doi.org/10.1080/026404102753576071

Lam, W. K., Ding, R., \& Qu, Y. (2017). Ground reaction forces and knee kinetics during single and repeated badminton lunges. Journal of sports sciences, 35(6), 587-592. https://doi.org/10.1080/02640414.2016.1180420

Li, S., Zhang, Z., Wan, B., Wilde, B., \& Shan, G. (2017). The relevance of body positioning and its training effect on badminton smash. Journal of sports sciences, 35(4), 310-316. https://doi.org/10.1080/02640414.2016.1164332 
Mansec, Y.L., Pageaux, B., Nordez, A., Dorel, S., \& Jubeau, M. (2018). Mental fatigue alters the speed and the accuracy of the ball in table tennis. Journal of Sports Sciences, 36, 2751 - 2759. https://doi.org/10.1080/02640414.2017.1418647

Mei, Q., Gu, Y., Fu, F., \& Fernandez, J. (2017). A biomechanical investigation of right-forward lunging step among badminton players. Journal of sports sciences, 35(5), 457-462. https://doi.org/10.1080/02640414.2016.1172723

Ooi, C. H., Tan, A., Ahmad, A., Kwong, K. W., Sompong, R., Mohd Ghazali, K. A., \& Thompson, M. W. (2009). Physiological characteristics of elite and sub-elite badminton players. Journal of sports sciences, 27(14), 1591-1599. https://doi.org/10.1080/02640410903352907

Reid, M., Giblin, G., \& Whiteside, D. (2015). A kinematic comparison of the overhand throw and tennis serve in tennis players: How similar are they really?. Journal of Sports Sciences, 33(7), 713-723. https://doi.org/10.1080/02640414.2014.962572

Rusdiana, A. (2016). Running speed device development using a microcontroller with a computer system interface. International Journal of Control and Applications, 9(28), 01-18.

Sakurai, S., \& Ohtsuki, T. (2000). Muscle activity and accuracy of performance of the smash stroke in badminton with reference to skill and practice. Journal of sports sciences, 18(11), 901-914. https://doi.org/10.1080/026404100750017832

Phomsoupha, M., \& Laffaye, G. (2014). Shuttlecock velocity during a smash stroke in badminton evolves linearly with skill level. Computer methods in biomechanics and biomedical engineering, 17 Suppl 1, 140-141. https://doi.org/10.1080/10255842.2014.931550

Wagner, H., Pfusterschmied, J., Von Duvillard, S. P., \& Müller, E. (2012). Skill-dependent proximal-to-distal sequence in team-handball throwing. Journal of Sports Sciences, 30(1), 21-29. https://doi.org/10.1080/02640414.2011.617773 